\title{
A network of autonomous surface ozone monitors in Antarctica: technical description and first results
}

\author{
S. J.-B. Bauguitte ${ }^{1, *}$, N. Brough ${ }^{1}$, M. M. Frey ${ }^{1}$, A. E. Jones ${ }^{1}$, D. J. Maxfield ${ }^{1}$, H. K. Roscoe ${ }^{1}$, M. C. Rose ${ }^{1}$, and \\ E. W. Wolff ${ }^{1}$ \\ ${ }^{1}$ British Antarctic Survey, Natural Environment Research Council, Cambridge, UK \\ *now at: Facility for Airborne Atmospheric Measurements, National Centre for Atmospheric Science, \\ Cranfield University, Cranfield, UK
}

Received: 26 November 2010 - Published in Atmos. Meas. Tech. Discuss.: 20 December 2010

Revised: 25 March 2011 - Accepted: 28 March 2011 - Published: 1 April 2011

\begin{abstract}
A suite of 10 autonomous ozone monitoring units, each powered using renewable energy, was developed and built to study surface ozone in Antarctica during the International Polar Year (2007-2009). The monitoring systems were deployed in a network around the Weddell Sea sector of coastal Antarctica with a transect up onto the Antarctic Plateau. The aim was to measure for a full year, thus gaining a much-improved broader view of boundary layer ozone seasonality at different locations as well as of factors affecting the budget of surface ozone in Antarctica. Ozone mixing ratios were measured based on UV photometry using a modified version of the commercial 2B Technologies Inc. Model 202 instrument. All but one of the autonomous units measured successfully within its predefined duty cycle throughout the year, with some differences in performance dependent on power availability and ambient temperature. Mean data recovery after removal of outliers was on average $70 \%$ (range 44-83\%) and precision varied between 1.5 and $8 \mathrm{ppbv}$, thus was sufficiently good to resolve year-round the main ozone features of scientific interest. We conclude that, with adequate power, and noting a minor communication problem, our units would be able to operate successfully at ambient temperatures down to $-60^{\circ} \mathrm{C}$. Systems such as the one described in this paper, or derivatives of it, could therefore be deployed either as local or regional networks elsewhere in the Arctic or Antarctic. Here we present technical information and first results from the experiment.
\end{abstract}

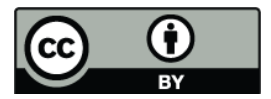

Correspondence to: A. E. Jones (aejo@bas.ac.uk)

\section{Introduction}

Ozone plays a central role within the chemistry of the troposphere. It is both an oxidant in its own right, and a precursor to other highly reactive trace gases, in particular the $\mathrm{OH}$ radical. At high southern latitudes, the seasonal cycle of ozone is characterised generally by a wintertime maximum of roughly $30 \mathrm{ppbv}$ (parts per billion by volume) and summer minimum of roughly 10 to $15 \mathrm{ppbv}$. Until very recently it was assumed that the chemical ozone budget in Antarctica was very simple, driven predominantly by transport during the winter time and photochemical destruction during the summer months. However, recent measurements have revealed that the chemical ozone budget is considerably more complicated, and is controlled by a number of subtle and complex processes whose influence varies with geographical location. For example, inland at South Pole and Concordia stations, measurements of surface ozone show a pronounced shoulder during late spring and early summer (Helmig et al., 2007; Legrand et al., 2009). This is now recognised to be driven by emissions of $\mathrm{NO}_{\mathrm{x}}$ from the snow surface (Crawford et al., 2001; Jones and Wolff, 2003) which arise from the photolysis of nitrate impurities within the snow (Honrath et al., 1999; Jones et al., 2000). Photolysis of $\mathrm{NO}_{2}$ is the only chemical source of ozone in the troposphere, but such net in situ production of ozone has, until recently, been associated solely with polluted environments. Further, at coastal sites such as Halley and Neumayer in the Weddell Sea sector, and McMurdo in the Ross Sea sector of Antarctica, surface ozone measurements during springtime show massive sporadic departures from the seasonal mean (Wessel et al., 1998; Jones et al., 2006; Helmig et al., 2007). Ozone concentrations

Published by Copernicus Publications on behalf of the European Geosciences Union. 
can drop episodically to instrument detection limits (below a few ppbv), and can remain suppressed for several days. These "Ozone Depletion Events" (ODEs) are driven by halogen chemistry, predominantly bromine, with a source associated with the sea ice zone (Simpson et al., 2007). Such features are also widely observed at coastal sites in the Arctic (e.g. Barrie et al., 1988; Helmig et al., 2007). Furthermore, measurements of ozone have been made from ships during springtime over the frozen Arctic Ocean, revealing periods up to several weeks during which near-zero ozone concentrations were measured (Bottenheim et al., 2009; Jacobi et al., 2006). These data raise the question of just how extensive ozone depletion over the sea ice zone really is. Similar work over the Antarctic sea ice zone has not yet been carried out. In addition to ship-borne observations, a possible tool to make measurements of surface ozone within the sea ice zone would be the recently developed autonomous O-buoy (Knepp et al., 2010).

The detailed climatology of tropospheric ozone over Antarctica is relatively understudied. Observations of yearround surface ozone have, until now, been tied to manned research stations generally confined to coastal Antarctica, with the exception of South Pole and Concordia continental stations on the East Antarctic Plateau. Thus far, the only information available for the vast region between the coast and plateau are spot measurements of boundary layer ozone during summer from the scientific over-land traverses (Frey et al., 2005) and airborne campaigns (Slusher et al., 2010). The vertical profile of ozone in the troposphere cannot be measured from satellites because the much larger amount of ozone in the stratosphere makes the discrimination of the tropospheric amount difficult for a limb-viewing sensor. Estimates of total ozone in the tropical troposphere have been made by subtracting the stratospheric ozone column (determined by a limb-viewing sensor) from the total ozone column (measured by a nadir-viewing sensor) (Fishman et al., 1990). However, as no tropospheric profile information is accessible by satellites, it is not possible to examine the spatial distribution of surface ozone from space. As a result of these limitations, a dearth of information has existed regarding the spatial gradient of surface ozone across Antarctica and how that varied through the year. Furthermore, there has been little information regarding the spatial extent of ozone-depleted air masses during Antarctic springtime.

In response to these knowledge and data gaps, a suite of ten autonomous surface ozone monitors, complete with renewable power supplies, was developed and built at the British Antarctic Survey (BAS). The units were deployed in a network along the south east Weddell Sea coast, and on a transect up to the Antarctic Plateau. The overall aim of the project was to gain a broad view of the surface ozone budget - the balance between halogen-driven destruction and production via snowpack emissions of $\mathrm{NO}_{\mathrm{x}}$, as well as assessing the regional extent of Antarctic ozone depletion during the spring. Here we present a technical description of the
Table 1. Site descriptions for the autonomous ozone monitoring system deployments.

\begin{tabular}{|c|c|c|c|}
\hline Site & Location & $\begin{array}{l}\text { Altitude } \\
\text { (ma.s.l.) }\end{array}$ & $\begin{array}{l}\text { Max and min } \\
\text { recorded temperature }\end{array}$ \\
\hline A & $\begin{array}{l}\text { Riiser Larsen } \\
72^{\circ} 36^{\prime} \mathrm{S} 018^{\circ} 23^{\prime} \mathrm{W}\end{array}$ & coastal & $+4^{\circ} \mathrm{C}$ to $-34^{\circ} \mathrm{C}$ \\
\hline B & $\begin{array}{l}\text { Lyddan Ice Rise } \\
74^{\circ} 04^{\prime} \mathrm{S} 021^{\circ} 49^{\prime} \mathrm{W}\end{array}$ & coastal & $+1{ }^{\circ} \mathrm{C}$ to $-37^{\circ} \mathrm{C}$ \\
\hline $\mathrm{C}$ & $\begin{array}{l}\text { Stancombe Wills - lower transect } \\
75^{\circ} 24^{\prime} \mathrm{S} 017^{\circ} 44^{\prime} \mathrm{W}\end{array}$ & $\sim 500$ & $-5^{\circ} \mathrm{C}$ to $-40^{\circ} \mathrm{C}$ \\
\hline $\mathrm{D}$ & $\begin{array}{l}\text { Stancombe Wills - mid transect } \\
75^{\circ} 55^{\prime}, \mathrm{S} 016^{\circ} 50^{\prime} \mathrm{W}\end{array}$ & 1030 & $-4{ }^{\circ} \mathrm{C}$ to $-46^{\circ} \mathrm{C}$ \\
\hline $\mathrm{E}$ & $\begin{array}{l}\text { Stancombe Wills - upper transect } \\
76^{\circ} 23^{\prime} \mathrm{S} 014^{\circ} 58^{\prime} \mathrm{W}\end{array}$ & $\sim 2000$ & $-11^{\circ} \mathrm{C}$ to $-45^{\circ} \mathrm{C}$ \\
\hline $\mathrm{F}$ & $\begin{array}{l}\text { Dronning Maud Land Plateau - } \\
\text { top transect } \\
76^{\circ} 15^{\prime} \mathrm{S} 007^{\circ} 30^{\prime} \mathrm{W}\end{array}$ & 2630 & $-16^{\circ} \mathrm{C}$ to $-63^{\circ} \mathrm{C}$ \\
\hline G & $\begin{array}{l}\text { Luitpold Coast North } \\
76^{\circ} 16^{\prime} \mathrm{S} 027^{\circ} 27^{\prime} \mathrm{W}\end{array}$ & coastal & $+3{ }^{\circ} \mathrm{C}$ to $-39^{\circ} \mathrm{C}$ \\
\hline $\mathrm{H}$ & $\begin{array}{l}\text { Luitpold Coast South } \\
76^{\circ} 58^{\prime} \mathrm{S} 031^{\circ} 22^{\prime} \mathrm{W}\end{array}$ & coastal & $+1{ }^{\circ} \mathrm{C}$ to $-36^{\circ} \mathrm{C}$ \\
\hline I & $\begin{array}{l}\text { Filchner Ice Shelf North } \\
78^{\circ} 13^{\prime} \mathrm{S} 037^{\circ} 32^{\prime} \mathrm{W}\end{array}$ & coastal & $-2{ }^{\circ} \mathrm{C}$ to $-49^{\circ} \mathrm{C}$ \\
\hline $\mathrm{J}$ & $\begin{array}{l}\text { Filchner Ice Shelf South (inland) } \\
79^{\circ} 56^{\prime} \mathrm{S} 034^{\circ} 45^{\prime} \mathrm{W}\end{array}$ & 125 & $-2{ }^{\circ} \mathrm{C}$ to $-63^{\circ} \mathrm{C}$ \\
\hline
\end{tabular}

autonomous monitoring system, review the performance of the systems, and present first results from the network.

\section{Location of the ozone network}

The ten units of the autonomous network were deployed during December 2007 and January 2008 and operated until $\sim$ January 2009. Their locations and site descriptions are given in Fig. 1 and Table 1 respectively. In addition to the autonomous units, surface ozone measurements from certain coastal stations in the region were also included in the study, although their data are not discussed here.

The network was specifically designed to address targeted scientific questions. Sites A, B, G, H and I were located to study the spatial extent of ODEs along the Weddell Sea coast. Sites B, C, D, E, F comprised a transect from the coast to 2630 m a.s.l. (above sea level) on the Dronning Maud Land (DML) Plateau, to assess how far inland, and to what altitudes, ODEs were evident. Their data could also be used to study the interplay and dominance of processes driven by halogen chemistry versus snow photochemistry throughout the year. Sites I and J were both on the Filchner Ice Shelf, so at similar altitudes above sea level, but Site I was directly on the coast whereas Site J lay $200 \mathrm{~km}$ inland. They were positioned to study how far inland depleted air masses could be observed when there was little change in altitude. 


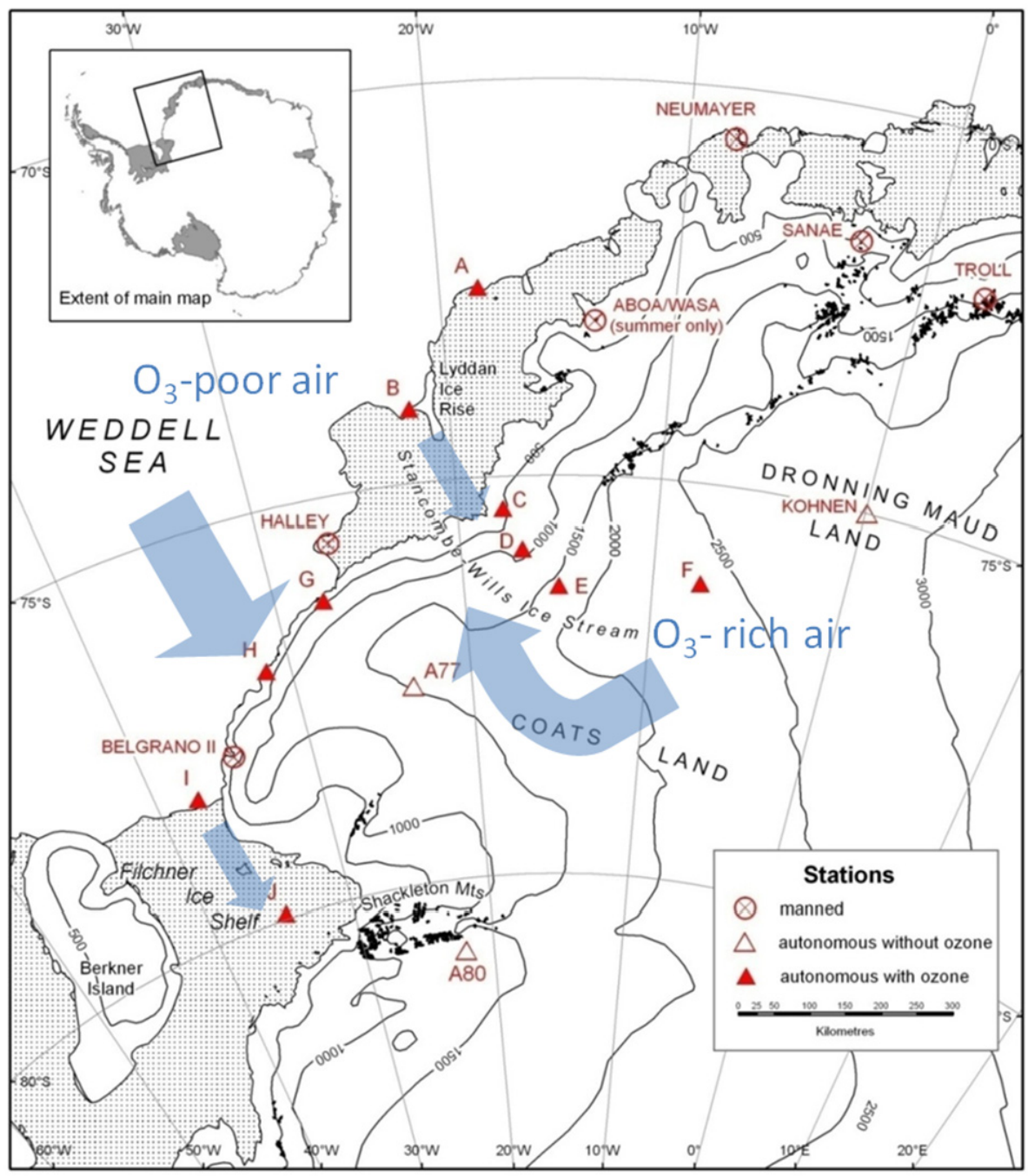

Fig. 1. Map showing location of the autonomous surface ozone monitors, as well as manned research stations that contributed data to the network and approximate trajectories of ozone-poor and ozone-rich air that drove the science aims.

\section{Instrumentation}

\subsection{The overall system}

Each monitoring unit consisted of an ozone monitor and equipment to generate power from both solar radiation and wind (see Fig. 2). A schematic of the overall set-up for each unit is given in Fig. 2a, and a photo of one unit installed at its measurement location is given in Fig. 2b. The philosophy of the network and individual units was that it should be as simple and cost-effective as possible (both to build and deploy) while still meeting the design criterion of: (a) operating, and providing accurate data, under all the meteorological conditions that might be encountered, (b) having sufficient power to provide adequate coverage of the trends and events of scientific interest, (c) having a common timestamp so that the results can be treated as a common network. These criteria allowed us to avoid the complications of long-range data transmission, since neither communication between the units nor communication of data before the end of the campaign, were required.

\subsection{The ozone monitor}

The chosen ozone monitor was a 2B Technologies Inc. Model 202, which is a single beam UV photometric instrument that measures ozone through absorption of light at $254 \mathrm{~nm}$ (see Wilson and Birks, 2006, for description). These instruments are well suited for measurements in remote environments, being small, lightweight, low-powered, and easy to operate (e.g. Hintsa et al., 2004). The units for the autonomous network were further customised as follows. A miniature rotary vanes air pump (Thomas ASF model G12/01 EB) was tested successfully in a freezer at BAS, 


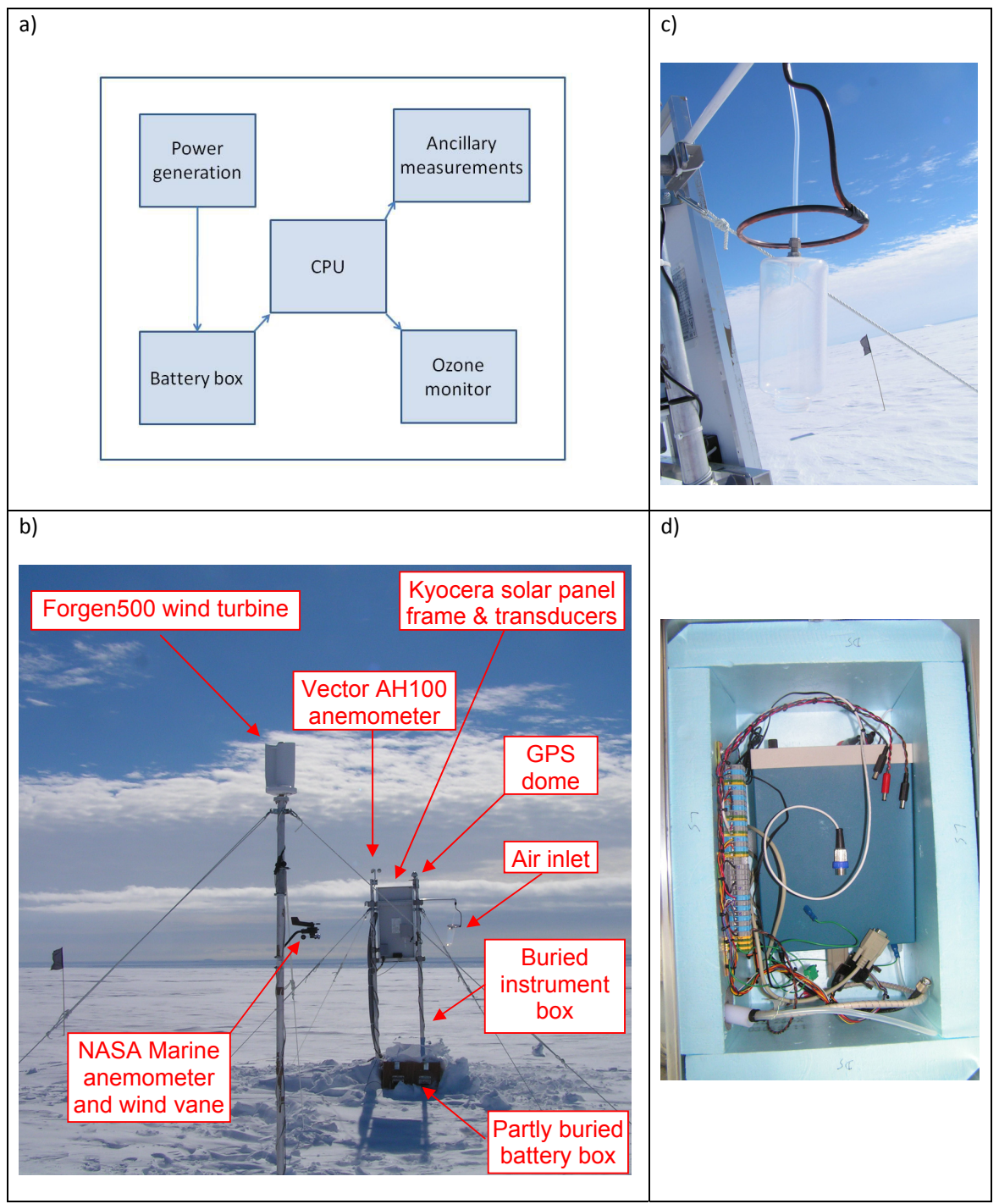

Fig. 2. (a) Schematic of the autonomous ozone monitor system - the blue arrows indicate flow of power; (b) photo of a complete unit installed and measuring; (c) detail of the Teflon inlet system - the metal hoop both holds the inlet tube in place during strong winds, and provides a robust surface against which to knock off any accumulating ice; (d) plan view of the insulated instrument box that housed the ozone monitor (shown) and also the CPU logger enclosure (not shown).

Cambridge, down to $-40^{\circ} \mathrm{C}$, and selected over the Sensidyne air pump (model 801516-V, series A, Viton diaphragm) usually fitted in ozone monitors Model 202, as we found the latter to fail at sub-zero temperatures. Thomas ASF guaranteed a maximum of 6 months continuous operation for our selected model. Three different 3-way electrosolenoid valves (used for $I / I_{\mathrm{O}}$ channels selection) were also tested in freezers at BAS for sub-zero operation; we selected ASCO model AL2312. 2B Technologies were consulted over customising the layout of the optical bench to accommodate additional heat tracing and thermal insulation. However after testing the Hg-lamp, we found that the lamp block was capable of igniting with starting temperatures as low as $-22^{\circ} \mathrm{C}$ without requiring heat tracing. Modifications also involved the removal of the front panel LCD display (power saving). A panel-mounted connector allowed a temporary, removable display to be plugged to the ozone monitor for diagnostics information during system set-up. A built-in Compact Flash card writer was also provided in the monitors as backup for the RS232 data stream destined for external logging. The instruments have a manufacturer specification of accuracy and precision for $1 \mathrm{~min}$ data of $1.5 \mathrm{ppbv}$ or $2 \%$ of reading once corrected for long-term drift, and a limit of detection of 3 ppbv. The customised units had a power consumption of $5 \mathrm{~W}$. Data (timestamp, ozone mixing ratios, UV absorption cell temperature and pressure) were logged as $1 \mathrm{~min}$ averages of $10 \mathrm{~s}$ measurements. 
The air pump within each unit provided a sampling airflow of approximately $1.3 \mathrm{Lpm}$. The air inlet was built entirely out of Teflon (Fluoroline 1/4" od PFA tubing and Nalgene FEP $1000 \mathrm{~mL}$ wide mouth bottle for inlet tip) and was supported $\sim 2 \mathrm{~m}$ a.s.l. (see Fig. 2c). A copper hoop around the inlet tip both held the inlet in place during strong winds and provided a robust surface against which the inlet system would knock, thus removing any accumulating ice. The ability of the unit to move also ensures that the inlet faces slightly away from the direction of any snowdrift, thus reducing ingress of snow.

The ozone monitor was housed in a heavily thermallyinsulated box (see Fig. 2d) constructed out of an aluminium transit case (Zarges Light Alloy $55 \times 35 \times 31 \mathrm{~cm}$ ), internally lined with low thermal conductivity $\left(0.028 \mathrm{~W} \mathrm{~m}^{-1} \mathrm{k}\right), 5 \mathrm{~cm}$ thick, extruded polystyrene panels (Dow Styrofoam Floormate 200), that became buried just under the snow surface. This meant that there was a temperature difference between the incoming air and the measuring unit. For most of the year it was expected that the ozone monitor would be warmer than the incoming air. For the periods when this was not the case, however, a $6 \mathrm{~W}$ heater, controlled by the control software, was used to prevent ambient water vapour freezing within the inlet tubing. Heat tracing was supplied along the majority of the $\sim 2 \mathrm{~m}$ length of the PFA sample tubing using a wound Nichrome 80 alloy round wire (Alloy Wire International), insulated in a $20 \mathrm{~mm}$ thick Armacell Tubolit DG PEF foam tube $\left(0.038 \mathrm{~W} \mathrm{~m}^{-1} \mathrm{k}\right)$. In spring and winter the inlet heater was only switched on when a comparison between air and snow temperatures suggested that ice deposition was a risk. During summer, when ambient temperatures were warmer, and solar energy was in plentiful supply, the inlet heater was on during all periods of instrument operation. Finally, sampling was suspended when the wind speed was above 25 knots $\left(\sim 13 \mathrm{~ms}^{-1}\right)$ to avoid any increased chance of snow ingress into the inlet line.

\subsection{Power supply}

Power was supplied by an environmental power supply from eXtreme Instrumentation (eXtreme Instrumentation Ltd., Cambridge, UK) which uses a $40 \mathrm{~W}$ Kyocera solar panel (Kyocera Corporation, Japan) and a vertical axis Forgen 500 wind turbine (Goodridge Engineering Ltd., Gloucester, UK). These systems have a long track record of successful operation in Antarctica (e.g. Kadokura et al., 2008). The vertical axis wind turbines have a natural maximum speed in strong winds, resulting in better reliability for Antarctic deployment than the more efficient horizontal axis turbines, which need to have additional protection to prevent failure in strong winds. The solar panel was installed facing north (i.e. towards the sun) and was angled vertically to maximise power output at low solar elevation angles and also to gain maximum radiation scattered from the snow. The Forgen 500 needs no control and along with the solar panel can be simply regulated to achieve the correct battery charge voltage.
The captured energy was stored in $200 \mathrm{Ah}$ of AGM lead acid gel cell batteries (i.e. $2 \times 100$ Ah batteries per battery box). At $5 \mathrm{~W}$ consumption, the batteries would potentially have $\sim 20$ days of reserve energy, although the cold temperatures would reduce this (see below) so the instrument would employ power saving strategies after about 10 days (e.g. by slowing the sampling rate). Further, once the battery voltage dropped below a threshold of $10 \mathrm{~V}$ the system would turn itself off and would not attempt re-start for a period (dependent on time of year but typically $24 \mathrm{~h}$ ) to allow the battery voltage to recover. This process prevented the batteries draining completely such that they would no longer function. The batteries were separately housed in a heavily insulated container that also contained the charging regulator.

In lead acid gell-cells, charge storage capacity decreases at low temperatures, more so at higher discharge rates. Compared to the $100 \mathrm{~A} \mathrm{~h}$ storage of our chosen batteries at $20^{\circ} \mathrm{C}$, tests at BAS showed that the capacity at $-40^{\circ} \mathrm{C}$ when being discharged at $80 \mathrm{~mA}$ fell to $50 \mathrm{Ah}$. Our discharge rates were either $100 \mathrm{~mA}$ or $200 \mathrm{~mA}$ per battery, hence we could get even greater reduction in storage at such low battery temperatures.

The ability to absorb charge by these batteries is reduced almost to zero at $-40^{\circ} \mathrm{C}$. If charging persists for long enough and the batteries are well enough insulated, this is self correcting, as the power from the wind or solar generator goes into warming the battery instead of being stored. Hence the battery eventually accepts charge. However, intermittent wind events in the winter will clearly not recharge cold batteries.

In the battery boxes, heat from both regulator and charging ameliorate these effects on both capacity and recharge.

As the batteries approach a fully charged condition their charge current declines and hence the amount of heat generated declines and the temperature stabilises or even falls, however the system contains circuitry that quashes the energy generation if the batteries get too warm. At the highest altitude site (Site F) and the highest latitude sites (Sites I and J), two battery boxes were used giving $400 \mathrm{Ah}$ of storage.

\subsection{Ancillary measurements}

A Trimble Lassen lower power miniature GPS module provided accurate time stamps and ensured that the data would be directly comparable between all of the sites.

Meteorological information was gained from external wind and temperature probes. At the majority of sites, ambient air temperature was measured using an Analog Devices' AD590KF temperature transducer, which has a stated temperature range for operation from $-55^{\circ} \mathrm{C}$ to $+150^{\circ} \mathrm{C}$. The AD590KF temperature transducer was placed within a radiation shield to protect it from direct sunlight (see Fig. 2b). AD590KF transducers were also employed to monitor the skin temperature of the Zarges transit case bottom panel, hence providing a proxy measurement of the snowpack 
temperature at the box burial depth. At all but 2 sites, a Vector $\mathrm{A} 100 \mathrm{H}$ anemometer was used to measure wind speed. At sites $\mathrm{D}$ and $\mathrm{G}$, automatic weather stations were available, such that air temperature and humidity were measured using a Vaisala HMP155 humidity probe in a radiation shield, wind speed and wind direction were measured with a RM Young 05103VM wind monitor, and pressure measured with a Vaisala PT100B analogue pressure transducer. At all sites, a low-cost NASA Marine mast head unit provided wind direction as well as wind speed and temperature, as back-up to the higher grade meteorological data. Further, house-keeping information was provided such as the main battery voltage and temperature and the regulated voltages for the logger and the GPS were also recorded.

All transducers signal and power multicore cables were passed through a side panel of the Zarges transit case via IP68 Amphenol connectors and distributed internally on DIN-rail mounted terminals.

\subsection{Logging and control}

Data logging and instrument control was performed by a Persistor CF2 embedded Central Processing Unit (CPU) that logged to its own $1 \mathrm{~GB}$ compact flash card. The CPU was housed along with the ozone monitor in the heavily thermally-insulated box. The CPU was mounted on a custom interface card, designed by the British Antarctic Survey, which provided the interfaces to RS485 and RS232 communications as well as the Trimble Lassen GPS NMEA data sentencing. The custom interface card also provided a watchdog timer and the solid state switches that allowed the CPU to power individual instruments only when they were needed. The duty cycle of the systems is discussed in more detail below. The CPU was programmed in the " $C$ " language and had software commands that could send it into low power modes when appropriate. When the units were active, ozone data and ancillary data were recorded every minute. Both the CPU and the GPS had dedicated lithium backup batteries to ensure sufficient power was always available to these critical components.

\section{Methodology}

\subsection{Calibration}

The Model 202 ozone monitors for the network were calibrated by the manufacturer before delivery to BAS, Cambridge. Soon after, calibration checks were carried out in Cambridge on three of the monitors using a UK National Physical Laboratory certified TEi49 PS (Thermo Electron instrument Primary Standard) to ensure that the systems were within specification. They were then shipped to Antarctica.

Further calibration tests were then carried out in Antarctica, prior to deployment, again on three monitors to check that the original calibration parameters were still valid. To achieve this, ozone generated by the internal ozoniser of a TEi Model 49C was fed, both to the TEi and to one of the Model 202s. Five calibration span levels ranging up to $200 \mathrm{ppbv}$, as well as zero, were used for the calibration checks. A minimum of $30 \mathrm{~min}$ stabilisation time was allowed, with a minimum of $15 \mathrm{~min}$ of measurements at each level. Agreement within instrumental uncertainties of the three systems was taken to indicate that all the Model 202s were still within their original calibration parameters outlined by the manufacturer (i.e. 2\%). The slope and offset parameters were then entered into the EEPROM (Electronically Erasable Programmable ROM chip) of each specific instrument.

After their year-round deployment, and before the instruments were removed from their respective measurement sites, instrument checks were performed such as a $\mathrm{Hg}$ lamp voltage check, a visual inspection of the inlet tubing for ice/snow ingress and an instrument offset (zero) check. This last was performed by sampling air through a charcoal scrubber for at least $15 \mathrm{~min}$ and noting the final averaged $\mathrm{O}_{3}$ concentration (see Table 2).

Once returned to Halley, all ten of the Model 202 ozone monitors were once again checked against the recentlycalibrated TEi Model 49C, using the method outlined above. On return to BAS Cambridge, the field calibrations of all ten of the Model 202 ozone monitors was re-checked against the TEi49 PS, and found to be robust. The pre-deployment and post-deployment calibration data are included in Table 2.

\subsection{Installation}

The units were installed on the snow surface, the solar panels and wind turbine supported on long poles (see Fig. 2b). It was anticipated that the two insulated boxes, the first containing the ozone monitor/CPU logger enclosure and the second containing the battery system, would be rapidly buried by snow accumulation. Indeed, burial occurred at all but one site (the high altitude Site F). Insulation by snow would provide protection from static build-up likely to occur during the frequent Antarctic blowing snow events, as well as damping diurnal variations in temperature. Such shallow burial, however, would not insulate against the extreme low temperatures of the Antarctic winter. Deeper burial reduces the amplitude of temperature variations, with seasonal variations at $10 \mathrm{~m}$ depth reduced to about $5 \%$ of that experienced in the air above the surface (Cuffey and Paterson, 2010). However, increasing the depth of burial is not necessarily practical given the need to deploy the instruments in a short time, and is also not likely to solve all the issues of low temperature. For some sites future deployments might consider additional insulation, or even additional heating (along with the necessary extra power generation and storage).

Installation of each unit was carried out by a team of two people. Because the units are light $(\sim 200 \mathrm{~kg}$ including batteries) it was possible to deploy 2 units with a single 
Table 2. Pre- and post-deployment calibration parameters.

\begin{tabular}{ccrcrr}
\hline Site & $\begin{array}{c}\text { Pre deployment } \\
\text { calibration } \\
\text { slope }\end{array}$ & $\begin{array}{c}\text { Pre deployment } \\
\text { calibration } \\
\text { offset }\end{array}$ & $\begin{array}{c}\text { Post deployment } \\
\text { calibration } \\
\text { slope }\end{array}$ & $\begin{array}{c}\text { Post deployment } \\
\text { calibration } \\
\text { offset }\end{array}$ & $\begin{array}{r}\text { Post deployment } \\
\text { background }\end{array}$ \\
\hline A & 1.04 & -2 & 1.00 & 0 & $0.6 \pm 2.9$ \\
B & 1.02 & -2 & 1.02 & 0 & $-0.2 \pm 0.9$ \\
C & 1.03 & -1 & 1.01 & -1 & $-0.5 \pm 1.8$ \\
D & 1.05 & -7 & 1.00 & -11 & $-8.8 \pm 0.6$ \\
E & 1.03 & -1 & 0.66 & 0 & $-0.7 \pm 2.9$ \\
F & 1.06 & 0 & 1.02 & 1 & $0.1 \pm 1.5$ \\
G & 1.03 & -1 & 1.00 & -1 & $-0.3 \pm 3.2$ \\
H & 1.04 & -5 & 1.00 & -11 & $-11.8 \pm 1.2$ \\
I & 1.02 & 1 & 0.93 & 2 & $1.2 \pm 1.8$ \\
J & 1.01 & -1 & 0.96 & 0 & $-0.7 \pm 1.4$ \\
\hline
\end{tabular}

operation by Twin Otter aircraft. Deployment at each site required approximately 3 to $4 \mathrm{~h}$.

\subsection{Duty cycle}

Whether the instruments were switched on (and if so, what their sampling rates were) was under software control. The system ran a 2-h repeat cycle, whereby at the start of every $2 \mathrm{~h}$, the system checked power availability (battery regulated voltage greater than $10.0 \mathrm{~V}$ ), time of year (GPS time fixed), and environmental parameters (wind speed less than $\left.13 \mathrm{~ms}^{-1}\right)$. Based on these checks, the system either made measurements, or suspend sampling by a further $2 \mathrm{~h}$ after which the checks would be re-run.

Critically, all the sensors of the network were co-ordinated to wake up and measure at exactly the same time. Whether a measurement was made or not depended also on power availability. However, with sufficient power to enable measurements, all the ozone monitors across the network measured in tandem so that data from all the monitors would be directly comparable.

A key requirement of the systems was to provide as close as possible to continuous ozone measurements during the spring period in order to assess the precise timing of ODEs across the region of the network. Practically, this meant recording a measurement every $60 \mathrm{~s}$ from 1 August until the end of October 2008. The systems nonetheless operated with the 2-h repeat cycle, checking the status of the system and time of year before each 2 -h measurement block. During these checks, the ozone monitor, and thereby the $\mathrm{Hg}$ lamp, was off and no measurements were made. One consequence was that, while the lamp was off, the cell temperature dropped by roughly $1^{\circ} \mathrm{C}$ and then took a few minutes to regain its previous temperature after the lamp was re-ignited (see Fig. 10b). No detrimental effect on the ozone measurements was apparent in the data, although 2 min of data were lost at the start of every $2 \mathrm{~h}$ block while the checks were being made.

In order to ensure that the batteries were not depleted when the springtime measurements were required, the system performed a considerably reduced sampling regime during the winter period (mid-April to end July 2008) with only $2 \mathrm{~h}$ of measurements every 3 days. The instrument's response to this is described below. Although making very limited measurements, this approach would nonetheless capture the smooth change in ozone anticipated for the winter months. For the remaining summer months, although solar power was plentiful, operation of the instrument was limited to $2 \mathrm{~h}$ out of every 6 to limit wear on the ozone monitor's rotary vanes air pump. Given the duty cycle described above, a perfectly functioning system, without suspended sampling due to high wind conditions or reduced battery charge, would operate for $3550 \mathrm{~h}$ over one year.

\section{Technical performance}

The technical performance of the autonomous systems overall was very good, the biggest challenges lying in the local environmental conditions, specifically temperature, wind speed, and solar insolation. A summary of key operating parameters is given for all sites in Table 3. Here we examine in more detail one typical coastal site (Site G), and compare with two other sites that contrast in terms of latitude (and hence solar availability and somewhat lower temperatures Site J) and altitude (with considerably lower temperatures Site F).

\subsection{Environmental parameters}

Site $\mathrm{G}$ is a representative coastal site from the network, lying mid-way between the northernmost (Site A) and southernmost (Site I) coastal sites. The ambient conditions 
Table 3. Overview of key operating parameters and resulting data amount and quality for each site. Potential data coverage varies between sites reflecting dates they were commissioned and uploaded. The final (logged) data is the total time of measurements after (before) filtering and is compared to the potential data coverage. Filtering removes typically $<3 \%$ of logged data with the exception of sites E, F, I and $\mathrm{J}$ ( 7 , 36,16 and $12 \%$, respectively). The standard error of the 10-min averages is calculated as $1-\sigma$ of the filtered 1-min data (see text) divided by the square root of the number of measurements (i.e. 10). This is the best estimate of instrument precision under field conditions if one assumes that ambient $\mathrm{O}_{3}$ levels did not change by much during any given $10 \mathrm{~min}$ interval.

\begin{tabular}{llcrcrrr}
\hline Site & $\begin{array}{c}T_{\text {PCB }} \\
(\text { range), } \\
{ }^{\circ} \mathrm{C}\end{array}$ & $\begin{array}{c}T_{\text {Batt. box }} \\
\left(\begin{array}{r}\text { (range), } \\
{ }^{\circ} \mathrm{C}\end{array}\right.\end{array}$ & $\begin{array}{c}V_{\text {supply }} \\
<10.5 \mathrm{~V}, \\
\%\end{array}$ & $\begin{array}{c}\text { Potential data, } \\
\text { days }\end{array}$ & $\begin{array}{c}\text { Logged data, } \\
\text { days }(\%)\end{array}$ & $\begin{array}{c}\text { Final data, } \\
\text { days }(\%)\end{array}$ & $\begin{array}{c}\text { Standard error, } \\
\text { mean (range) } \\
\text { ppbv }\end{array}$ \\
\hline $\mathrm{A}$ & $(-28 ; 5)$ & $(-30 ; 23)$ & 9 & 150 & $97(64)$ & $94(62)$ & $0.8(0-4.0)$ \\
$\mathrm{B}$ & $(-31 ; 5)$ & $(-30 ; 22)$ & 3 & 148 & $101(68)$ & $99(67)$ & $1.0(0-21.1)$ \\
$\mathrm{C}$ & $(-36 ; 6)$ & $(-30 ; 20)$ & 4 & 149 & $123(82)$ & $119(80)$ & $0.9(0-9.1)$ \\
$\mathrm{D}$ & $(-38 ; 4)$ & $(-28 ; 23)$ & 7 & 149 & $107(72)$ & $104(70)$ & $0.6(0-5.3)$ \\
$\mathrm{E}$ & $(-39 ; 3)$ & $(-39 ; 21)$ & 4 & 148 & $108(73)$ & $100(68)$ & $1.4(0-12.1)$ \\
$\mathrm{F}$ & $(-61 ;-4)$ & $(-51 ; 9)$ & 3 & 147 & $65(44)$ & $42(28)$ & $1.5(0-8.2)$ \\
$\mathrm{G}$ & $(-28 ; 6)$ & $(-19 ; 28)$ & 5 & 152 & $120(79)$ & $117(77)$ & $0.8(0-9.0)$ \\
$\mathrm{H}$ & $(-33 ; 10)$ & $(-33 ; 29)$ & 3 & 158 & $114(72)$ & $112(71)$ & $0.5(0-12.1)$ \\
$\mathrm{I}$ & $(-43 ; 8)$ & $(-43 ; 17)$ & 16 & 148 & $96(65)$ & $80(54)$ & $0.8(0-13.6)$ \\
$\mathrm{J}$ & $(-48 ; 8)$ & $(-44 ; 19)$ & 7 & 149 & $123(82)$ & $108(73)$ & $0.8(0-6.3)$ \\
\hline
\end{tabular}

throughout the measurements period at Site G are shown in Fig. 3. For the majority of the year ambient air temperatures remain above $-25^{\circ} \mathrm{C}$, with occasional colder periods during the autumn (temperatures down to $-28^{\circ} \mathrm{C}$ ) and periods below $-30^{\circ} \mathrm{C}$ during both winter and spring. The lowest recorded ambient temperature for Site $\mathrm{G}$ was $-39^{\circ} \mathrm{C}$. The windiest period during the year was the spring, as is typical in Antarctic coastal regions, with storms gusting to $20 \mathrm{~ms}^{-1}$ a regular feature. During all other seasons, wind speeds over the $\sim 13 \mathrm{~ms}^{-1}$ sampling threshold were recorded, but considerable periods also occurred when wind speeds were sustained between 5 and $10 \mathrm{~ms}^{-1}$. Figure 3 also shows the availability of sunlight during the year at Site G, in the form of a solar elevation angle envelope. This shows that the sun remained above the horizon until 14 February 2008 and after 29 October 2008, but that there was no sunlight available at all from 30 April 2008 to 15 August 2008.

\subsection{Power generation}

Figure 4 shows output voltages of both the Forgen wind turbine and the solar panels from Site $G$ throughout the year. Also shown is the output voltage of the battery box. There are no direct measurements of current in the system, but the charging source that has the highest voltage will be supplying the greatest amount of power. Clearly, during periods of the year when the sun was above the horizon, the solar panels provided the majority of the power to the batteries. Even during the periods with a day/night cycle, the solar panel power generation ability was greater than that of the Forgen wind turbine, which only occasionally provided much charging current.

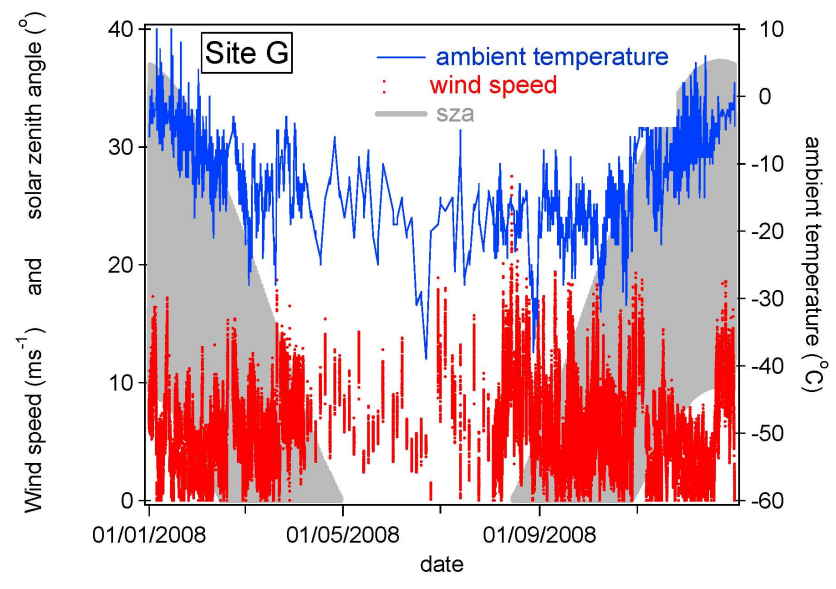

Fig. 3. Ambient environmental conditions (1 min measurements) at Site G, a location representative of the coastal sites in the network. Ambient air temperatures shown here were measured using the AD590KF temperature transducer. The grey shaded envelope marks the daily range of solar elevation angle; zero denotes the horizon, which the sun remains below during the polar winter.

During the dark winter months, power generation, of course, relied solely on wind. Some information regarding power generation exists and is shown in Fig. 4. The sporadic nature of the data reflects both the instrument duty cycle (only measuring for $2 \mathrm{~h}$ every 3 days), and also a communication problem outlined below. However it is clear that there was only very limited amounts of energy received from the wind generator.

As described earlier, the planned instrument duty cycle for the spring period was for continuous measurements. It was 


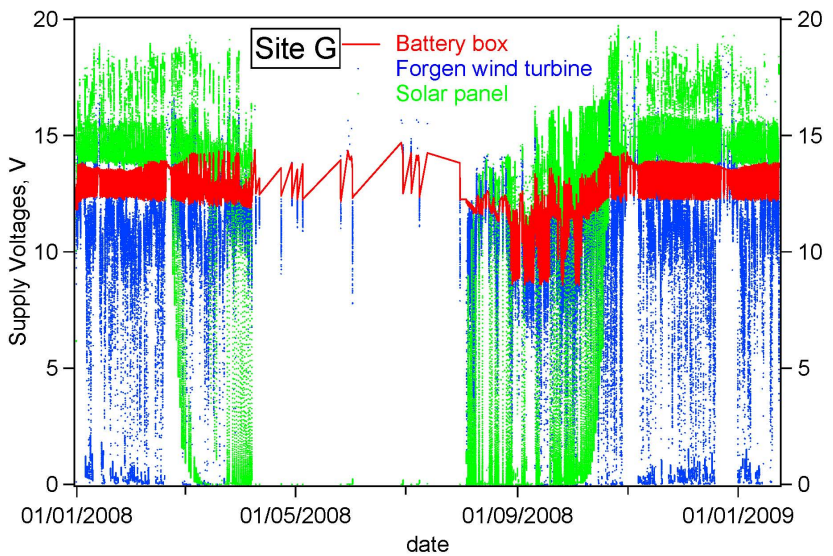

Fig. 4. Voltages generated by the wind turbine and solar panels during the year at Site G, as well as the supply voltage from the battery box (1 min measurements).

anticipated that sufficient power generation would be possible from available wind and solar sources. However, limitations to power generation arose for all sites, which resulted in unplanned and irregular downtime for the ozone monitors. Essentially the monitors ran until the battery supply voltage fell below its threshold limit, at which time the systems switched off while the batteries recharged.

\subsection{Influence of temperature on the logger}

The electronics was designed and tested to work down to $-40^{\circ} \mathrm{C}$. Figure 5 shows that for the majority of the year at Site G, the temperature of the instrument package tracked that of the surrounding snow, and remained above $-20^{\circ} \mathrm{C}$. Figure 5 also shows that the un-regulated CPU logger input voltage was relatively stable for the majority of the year: the period where large fluctuations are apparent is during the springtime, when battery charge and temperature are both changing rapidly with the heavy use of power and the availability of solar energy for recharging the batteries.

Even though a measurement of the CPU input voltage suggests that the CPU is functioning correctly, it is clear from the data gaps in Fig. 4 that there are periods during the winter when a malfunction has occurred. An examination of the system $\log$ file showed that the problem arose in the 2way communication: although the logger requested data correctly, none was supplied and therefore logged. These data gaps are more prevalent during the winter months, suggesting that the communication was not able to work reliably at the colder temperatures. However, although an examination of data from the other network sites showed that this error arose sporadically across the network, and was most prevalent during the winter, there did not seem to be a specific temperature at which the error occurred. It was clearly more prevalent at lower temperatures, but each system had a different temperature threshold for the problem to occur.

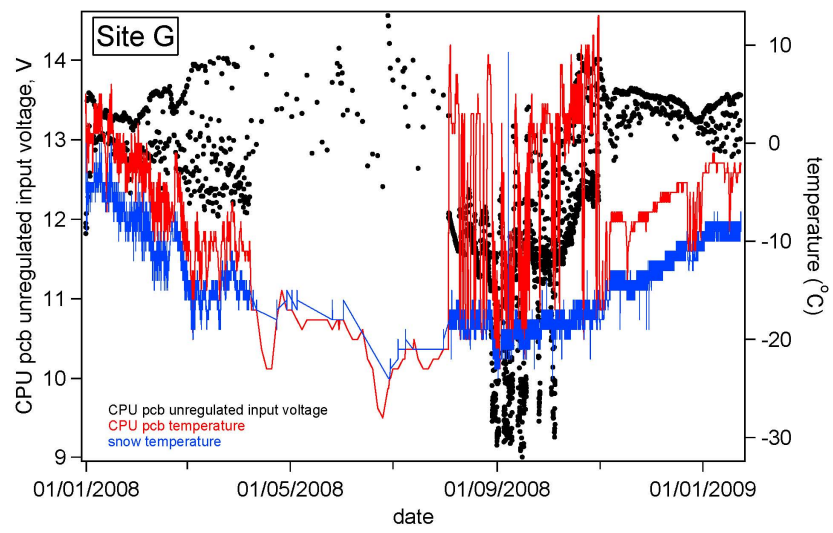

Fig. 5. CPU input voltage and temperature (6 hourly values), and snow temperature (1 min measurements) throughout the year at Site G.

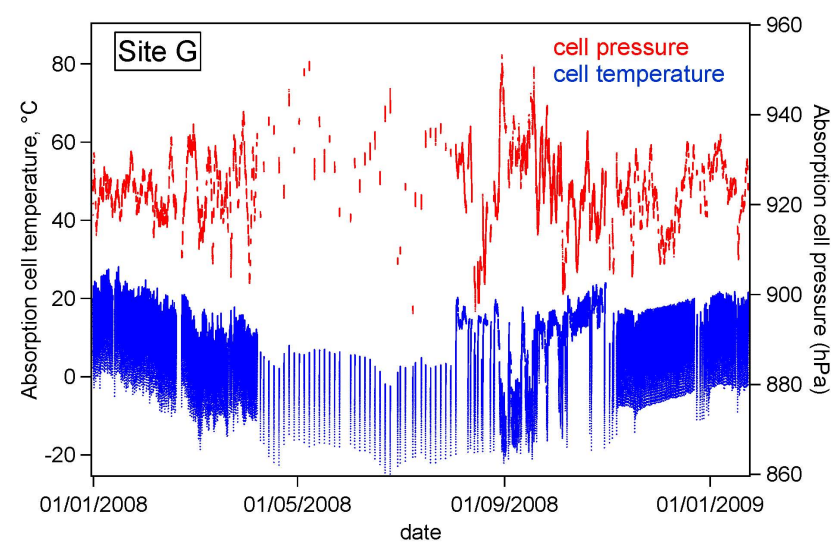

Fig. 6. Ozone monitor diagnostics (1 min data) throughout the year for the unit at Site G.

\subsection{Ozone monitor diagnostics}

Figure 6 provides information on the behaviour of the ozone monitor throughout the year. The UV absorption cell temperature varied in line with ambient, but generally remained above $-20^{\circ} \mathrm{C}$. The apparent envelope in cell temperature of $\pm 10^{\circ} \mathrm{C}$ arises as a result of the instrument duty cycle: when the instrument is switched "off", the cell temperature falls, and is therefore low when the instrument is next switched "on". During periods in the spring when the instrument is on continuously, the cell temperature is maintained within an envelope of around one degree. As discussed later, filtering was used to ensure that periods with strong cell temperature fluctuations were excluded from more processed datasets. Cell pressure was also recorded to provide diagnostics information on ice blockages in the sample flow system. During cold laboratory tests prior to deployment, we found pressure differences between ambient pressure and cell pressure ranging from $10-15 \mathrm{mb}$, slowly increasing when freezing water vapour at the inlet was not controlled. No such behaviour was 


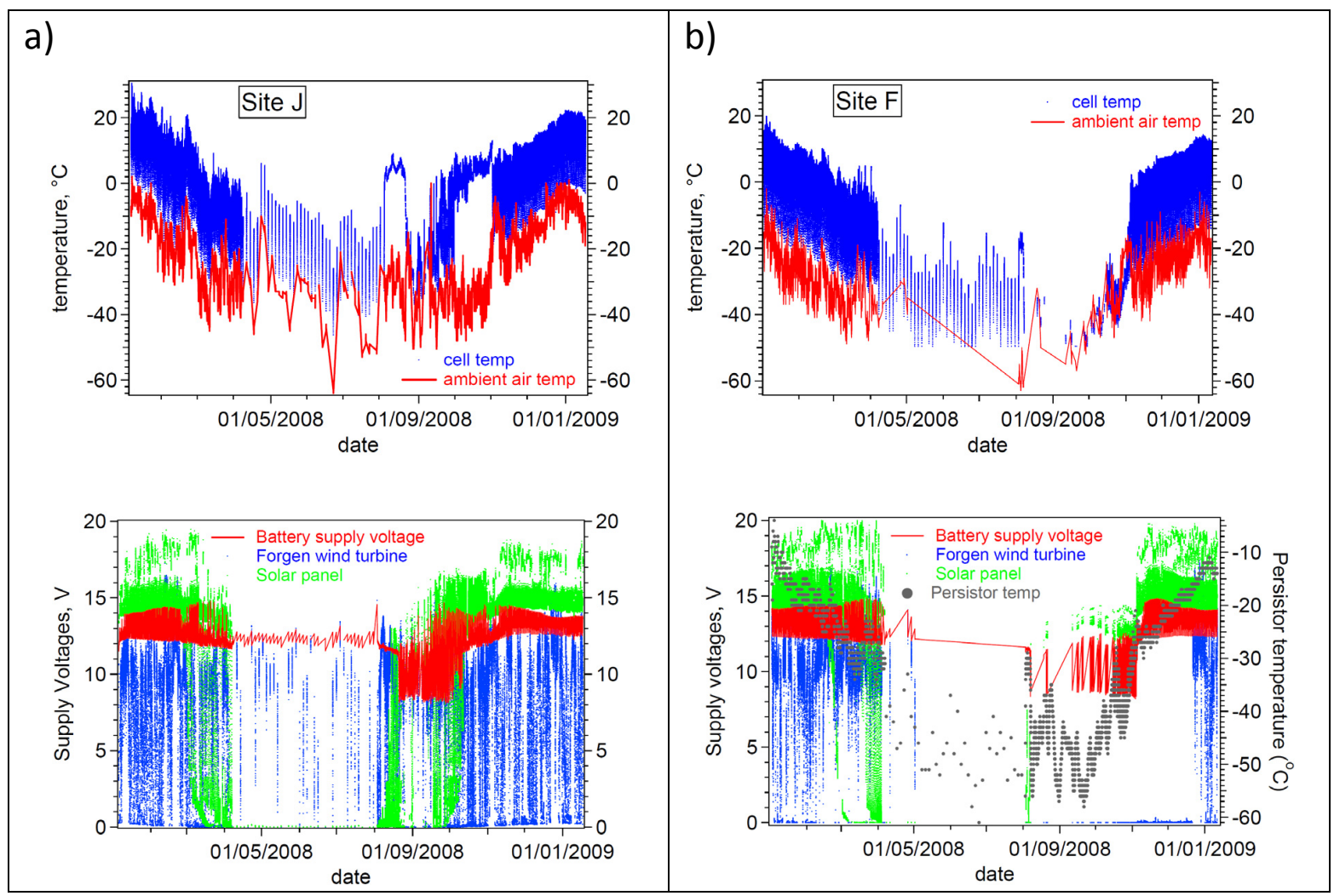

Fig. 7. Temperatures and power generation throughout the year at (a) Site J, a low altitude site at the most southerly latitude in the network; (b) at Site F, the coldest and highest altitude site, but at the same latitude as Site G. Data are shown at the same time resolution as for Site G.

experienced in any of the network systems when deployed indicating that ice blockages did not occur. This conclusion was supported by visual inspection of all internal plumbing prior to recovering the systems from the field. We note, further, that for all sites other than Site $\mathbf{J}$ (where minor damage was reported), the Teflon inlet systems were intact at the end of the year of measurements.

\subsection{Influence of latitude and temperature at other sites}

Site $\mathrm{J}$ lay $3^{\circ} 40^{\prime}$ further south than Site G, so had both a slightly longer winter period and lower ambient temperatures. The power generation budget at Site $\mathrm{J}$ is shown in Fig. 7a. The figure is very similar to that for Site G, with a mix of solar and wind providing energy for the majority of the year, with the input from the solar panels generally outperforming that from the wind turbine. As a result of the different latitude, there was a slightly longer wintertime period when the solar elevation was too low to provide power, but the difference was a mere matter of days at the start and end of the winter. The wind generator was more successful at this site in maintaining battery voltage throughout the winter. The additional useable wind power at the start of the spring, more than compensated for any reduction in solar energy.
Figure 7a also shows the data gaps in voltage information, indicative of the communication error described above. It is interesting to note that the system at Site $\mathrm{J}$ functioned better than that at Site $\mathrm{G}$, even though it was below $-30^{\circ} \mathrm{C}$ almost continuously from 8 April until 3 August (see Fig. 7a) while that at Site $\mathrm{G}$ never reached such low temperatures (see Figs. 3 and 6).

Site $F$ was at the equivalent latitude to Site $G$, but at $263 \mathrm{~m}$ a.s.l. on the Dronning Maud Land Plateau, it was in general the coldest location in the network (Fig. 7b). Figure $7 \mathrm{~b}$ also shows the power budget for Site $\mathrm{F}$ as well as the Persistor CPU temperature. From summer 2008 through to late autumn, the power budget appears very similar to the other sites, as it does during summer 2009. The period in between, however, appears very different. Immediately obvious are the considerable gaps in the battery supply voltage data, in particular one extending from early May to early August. These indicate the communication problem discussed above, and indeed Fig. $7 \mathrm{~b}$ shows that the CPU temperature was between roughly $-40^{\circ} \mathrm{C}$ and $-60^{\circ} \mathrm{C}$ during this time. It is also interesting to note that around the start of August, the CPU temperature rose to $-30^{\circ} \mathrm{C}$, and the system was able to $\log$ power generation from the solar panel and the battery supply voltage. 
Another striking difference at Site F is the lack of power generation from the Forgen wind generator during the springtime and the first half of the summer. It is likely that at the low temperatures experienced at Site F, the bearings of the turbine would have become stiff, requiring much greater torque to start and maintain rotation, a situation that would be compounded by icing. It appears that sufficient warming to get the system moving again did not occur until the end of December. The lack of wind power meant that measurements at Site F were supported solely by solar energy; from August through to end of October, the battery voltage averaged $10.1 \mathrm{~V}$ but remained below $12.5 \mathrm{~V}$. The battery was only charging properly from solar energy from the start of November, when the sun remained above the horizon for $24 \mathrm{~h}$ each day. It is interesting, however, to compare with Site J, where at similarly low temperatures, the system functioned correctly.

The power generation problems at Site F resulted in considerably lower UV absorption cell temperatures during the winter than at other sites, including Site J (Fig. 7). This had detrimental effects on the quality of the final ozone dataset, which had considerably more points removed because of low cell temperature and also more scatter, than at any other sites (see below and Table 3).

\section{Data quality and processing methodology}

For the majority of the autonomous monitors, data quality throughout the deployment was extremely good. An example of the quality of raw data is given in Fig. 8, which shows measurements made at Site $G$ for the whole of 2008. The noise in the data throughout the year is limited to roughly $\pm 8 \mathrm{ppbv}$ and even in these raw data springtime ozone depletion events are clearly visible.

Also apparent in the data is the change in measurement cycle during the winter, to sampling for only $2 \mathrm{~h}$ every 3 days. This change is shown in more detail in Fig. 9. Figure 9a shows data from late May to early July, and a single 2-h period of winter time measurements, on a day in mid June, is shown in Fig. 9b. Two things in particular are demonstrated here: the reduced data quality during the initial phase of measurements, as the lamp is re-ignited and the system warms up and settles down; and the high quality of system performance, even under the challenging conditions of Antarctic mid-winter, that is achieved once the instrument stabilises.

A similar plot for springtime data is shown in Fig 10. Figure 10a shows data from early August to early September 2008. At this site during spring, continuous measurements were achieved for up to a week, but frequent and irregular data gaps are also apparent. This is a feature in the data from all sites, arising from the inability of the power generation system to meet the power requirements for continuous operation at this time of year. Figure 10b shows detail of a short single period of measurement, on 23 August, where the

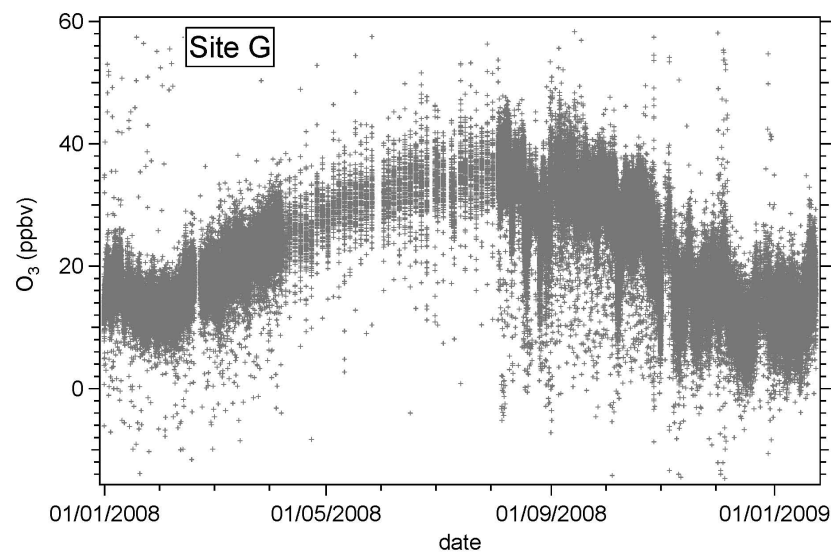

Fig. 8. An example of the 1-min raw data achieved by the monitoring system at Site $\mathrm{G}$ during its year-round deployment. A small number of outliers lie beyond the data range shown here.

measurement period lasted only for $\sim 10 \mathrm{~h}$. However, once again, the figure demonstrates the extremely good data quality achieved once the system had stabilised.

Final data sets were achieved by applying a simple series of filters. The precision of $\mathrm{O}_{3}$ mixing ratios showed significant deterioration when cell temperatures of the $\mathrm{O}_{3}$ monitor were low or were changing rapidly during warm up. A firstpass filter was therefore applied that removed records where cell temperature was below $-10^{\circ} \mathrm{C}$. Secondly, a noise filter was applied which removed any individual negative or positive outlier "spikes" that were greater than 3 times the average of a 10 min period before and after each "spike" (Fig. 11). The remaining data were then averaged over a variety of time intervals (daily, hourly, $10 \mathrm{~min}$ ) to allow analysis at different levels of detail. For example, the filtered $1 \mathrm{~min}$ data would be appropriate for studying synchronicity of ozone depletion events but daily data would be appropriate for studying the seasonal signal at different sites. The resulting data amount and quality for each site is given in Table 3.

\section{First results}

Figure 12a shows a full year of ozone measurements from Site G, processed according to the method outlined above, and at $1 \mathrm{~h}$ averages. Site $\mathrm{G}$ is located $\sim 80 \mathrm{~km}$ from the British Antarctic Survey station, Halley $\left(75^{\circ} 35^{\prime} \mathrm{S}, 26^{\circ} 34^{\prime} \mathrm{W}\right)$, where surface ozone is routinely measured using a Thermo Electron model 49C. This instrument has a manufacturer-stated detection limit and precision, respectively, of $1 \mathrm{ppbv}$, and the data are recorded every $1 \mathrm{~min}$. Figure $12 \mathrm{~b}$ shows yearround measurements from Halley that are coincident with those from Site G. The comparison between the two data sets is remarkably good. As well as the same broad annual cycle, with summer minimum of $\sim 10 \mathrm{ppbv}$ and winter maximum of $\sim 38 \mathrm{ppbv}$, smaller scale features during the summer 

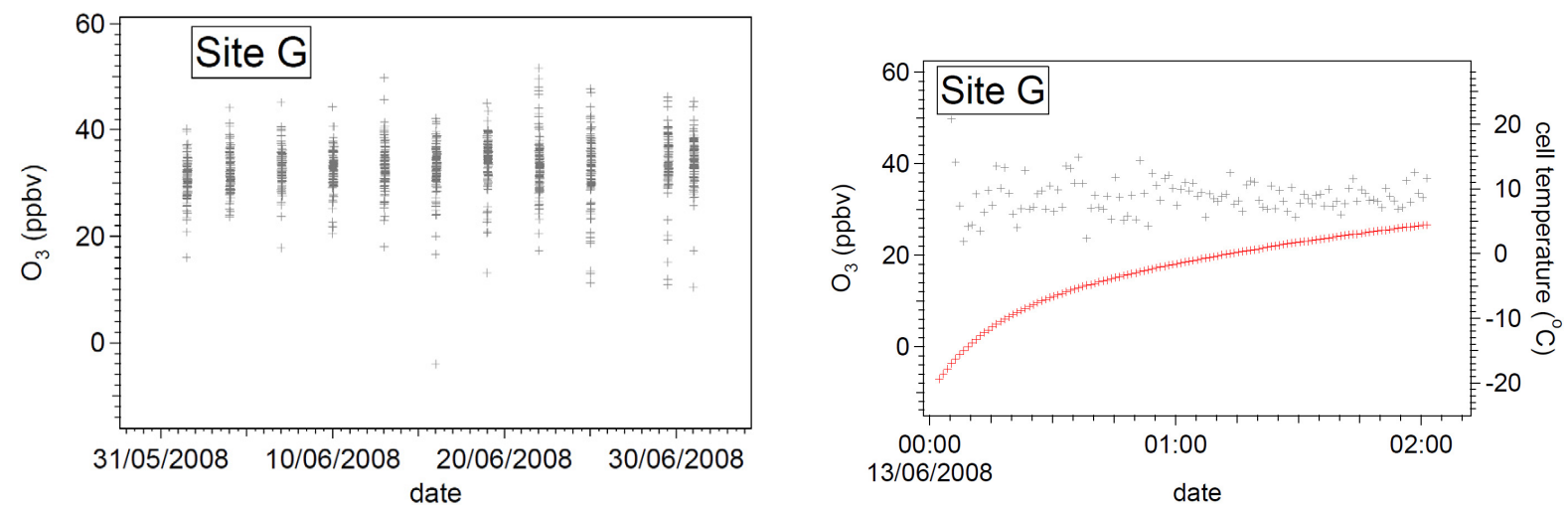

Fig. 9. Examples, from Site G, of ozone data sampling (black crosses) during the winter period: (a) for roughly 1 month of measurements, and (b) for a 2-h period. Panel (b) also shows the instrument cell temperature (red triangles) and how instrument response improves as the cell warms up and the system settles down. Data are shown as 1 min averages.
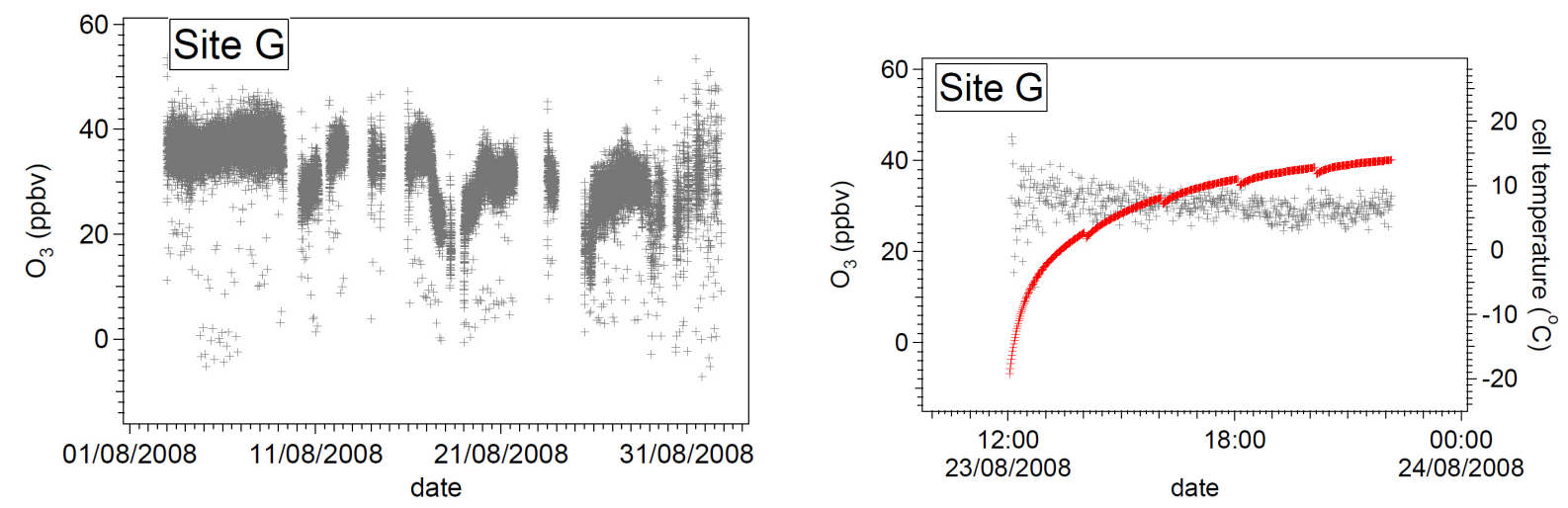

Fig. 10. Examples, from Site G, of ozone data sampling during springtime: (a) with irregular sampling duration and breaks resulting from insufficient power availability; (b) detail of a short single measurement period demonstrating the reduced data quality during warm-up phase and the extremely good data quality achieved once the cell had warmed up and the system had settled down (black crosses $=\mathrm{O}_{3}$ mixing ratio, red triangles $=$ cell temperature). Also apparent is the 2-h system repeat cycle, at the end of which the lamp is switched off briefly, such that cell temperature temporarily dips (see text for further explanation). Data are shown as 1 min averages.

months are evident in both datasets. For example, a small doublet in January 2008 appears in both datasets, albeit offset in time presumably by transport, and a more significant decline followed by a peak occurs concurrently at both sites in December 2008. There appears, further, to be considerable synchronicity in observed ozone depletion events during the spring. Indeed, the four clusters of major ODEs in the records are observed effectively simultaneously in both datasets. Although this is no great surprise from two sites so closely co-located, seeing it in the data provides confidence that features observed by the autonomous system are real, such that data from the wider network can be used to assess the scientific questions initially posed.

\section{Summary and conclusions}

A network of 10 autonomous surface ozone measurement systems was developed using a low-power ozone monitor supported by wind and solar power. The systems were deployed in Antarctica for a full year along the Weddell Sea coast and on a transect up to the Antarctic Plateau near Dronning Maud Land. A scientific analysis paper is in preparation that will fully describe the features in the data. All of the systems deployed at altitudes of $\sim 2000 \mathrm{~m}$ a.s.l. and below operated well throughout the measurement period, switching between measurement modes according to their pre-defined duty cycle. Some problems arose during springtime at all sites, when insufficient power was generated to support the desired continuous measurements, so enforced instrument downtimes occurred while the batteries re-charged. Further, at the highest altitude site (Site F), the instrument suffered at the very low winter temperatures with the result that 


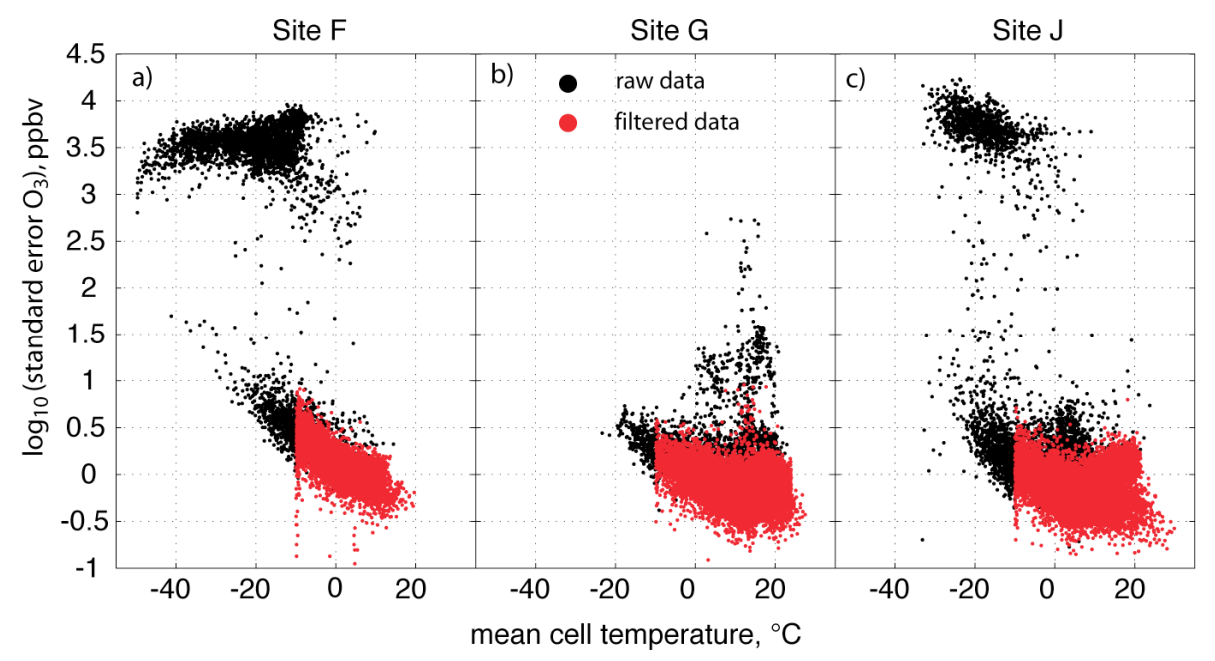

Fig. 11. The precision of $\mathrm{O}_{3}$ mixing ratios is estimated as the standard error of the 10 min averages and shows significant deterioration as cell temperatures of the $\mathrm{O}_{3}$ monitor drop or change rapidly during warm up. Data are therefore filtered by first removing records where cell temperature is below $-10^{\circ} \mathrm{C}$ and then using a statistical filter to suppress remaining outliers (see text). This approach results in a reduction in the logged number of records by 36,2 and $12 \%$ for sites F, G and J, respectively (see also Table 3 ).
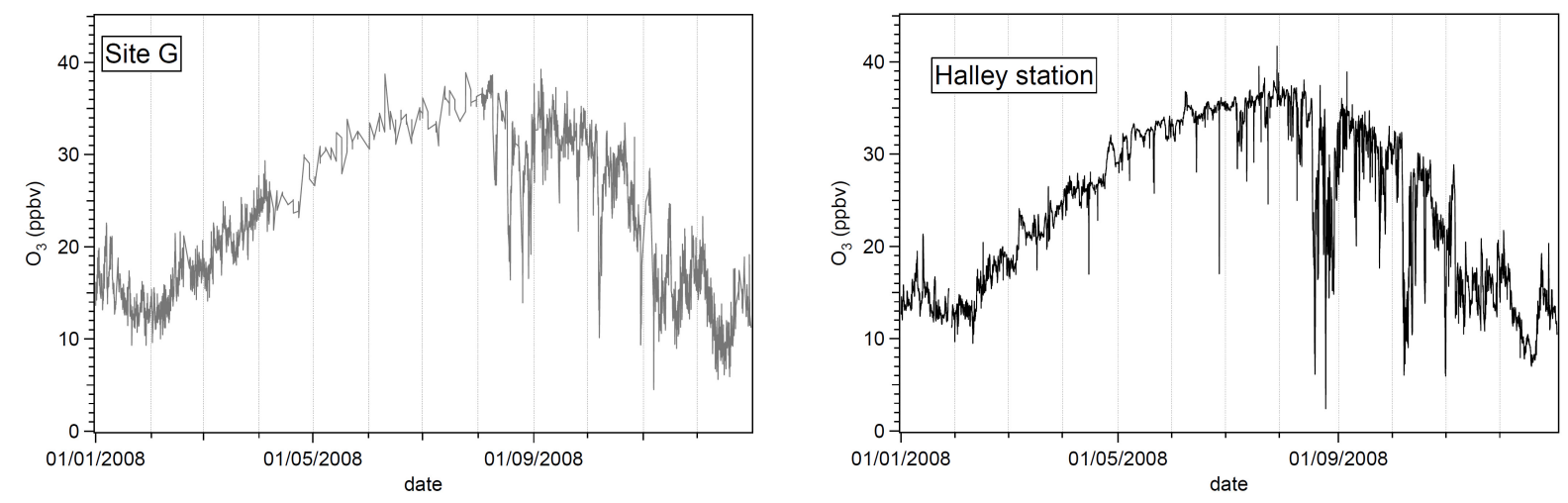

Fig. 12. Year-round measurements through 2008 from Site G compared with those from the nearby TECO-49C measuring at Halley station. Both datasets are shown here at 1-h averages.

power generation from the wind turbine was compromised, and ozone data quality was considerably reduced. However, at Site J, with similarly low temperatures, the system functioned correctly, even though regularly experiencing temperatures of $-50{ }^{\circ} \mathrm{C}$ and below. For future deployments at cold sites, additional thermal insulation, deeper burial, or additional heating (along with the necessary extra power generation and storage), could be included. Additional wind power should also be considered, whether from additional turbines, larger turbines, or turbines with better performance in the extreme cold. Additional thermal insulation or trickle heating may also avoid some communication problems with the CPU. A subset of the network instruments will be redeployed to Antarctica to study outflow from the Antarctic Plateau as part of the OPALE (Oxidant Production from Antarctic Lands and its Export) project .
It can therefore be concluded that, if adequate power had been supplied at all sites, and noting the communication problem, our units would be able to operate at the ambient conditions in winter down to $-60^{\circ} \mathrm{C}$. Systems such as the one described in this paper, or derivatives of it, could be deployed either as local or regional networks elsewhere in the Arctic or Antarctic. They are not currently tested at ambient temperatures below $-60^{\circ} \mathrm{C}$ nor in the more humid and salty conditions over sea ice, but it is reasonable to assume that, with some modifications, they could act as cost-effective and easily deployed networks throughout the polar regions. 
Acknowledgements. Particular thanks go to the British Antarctic Survey personnel who installed and uploaded the autonomous ozone monitoring systems. In particular, Andrew Rankin 's enthusiasm contributed to the smooth installation of the network in 2007/2008. We are grateful for the considerable support received from the BAS Operations and Logistics group during system deployment and retrieval. John Birks and his technical team at 2B Technologies Inc. provided prototypes and advice on specification for low temperature operation. We would like to thank Peter Kirsch and Paul Breen for help with data handling. This study is part of the British Antarctic Survey Polar Science for Planet Earth Programme. It was funded by the Natural Environment Research Council.

Edited by: J. Staehelin

\section{References}

Barrie, L. A., Bottenheim, J. W., Schnell, R. C., Crutzen, P. J., and Rasmussen, R. A.: Ozone destruction and photochemical reactions at polar sunrise in the lower Arctic atmosphere, Nature, 334, 138-141, 1988.

Bottenheim, J. W., Netcheva, S., Morin, S., and Nghiem, S. V.: Ozone in the boundary layer air over the Arctic Ocean: measurements during the TARA transpolar drift 2006-2008, Atmos. Chem. Phys., 9, 4545-4557, doi:10.5194/acp-9-4545-2009, 2009.

Crawford, J. H., Davis, D. D., Chen, G., Buhr, M., Oltmans, S., Weller, R., Mauldin, L., Eisele, F., Shetter, R., Lefer, B., Arimoto, R., and Hogan, A.: Evidence for photochemical production of ozone at the South Pole surface, Geophys. Res. Lett., 28, 3641-3644, 2001.

Cuffey, K. M. and Paterson, W. S. B.: The Physics of Glaciers, 4th edition, Butterworth-Heinemann, Oxford, 693 pp., 2010.

Fishman, J., Watson, C. E., Larsen, J. C., and Logan, J. A.: Distribution of Tropospheric Ozone Determined From Satellite Data, J. Geophys. Res., 95(D4), 3599-3617, doi:10.1029/JD095iD04p03599, 1990.

Frey, M. M., Stewart, R. W., McConnell, J. R., and Bales, R. C.: Atmospheric hydroperoxides in West Antarctica: links to stratospheric ozone and atmospheric oxidation capacity, J. Geophys. Res., 110, D23301, doi:10.1029/2005JD006110, 2005.

Helmig, D., Oltmans, S., Carlson, D., Lamarque, J.-F., Jones, A. E., Labuschagne, C., Anlauf, K., and Hayden, K.: A review of surface ozone in the polar regions, Atmos. Environ., 41, 51385161, doi:10.1016/j.atmosenv.2006.09.053, 2007.

Hintsa, E. J., Allsup, G. P., Eck, C. F., Hosom, D. S., Purcell, M. J., Roberts, A. A., Scott, D. R., Sholkovitz, E. R., Rawlins, W. T., and Mulhall, P. A.: A new ozone measurement system for autonomous measurements from ocean buoys and towers, J. Atmos. Ocean. Tech., 21, 1007-1016, 2004.

Honrath, R. E., Peterson, M. C., Guo, S., Dibb, J. E., Shepson, P. B., and Campbell, B.: Evidence of $\mathrm{NO}_{\mathrm{x}}$ production within or upon ice particles in the Greenland snowpack, Geophys. Res. Lett., 26, 695-698, 1999.
Jacobi, H. W., Kaleschke, L., Richter, A., and Rozanov, A.: Observations of a fast ozone loss in the marginal ice zone of the Arctic Ocean, J. Geophys. Res., 111, D15309, doi:10.1029/2005JD006715, 2006.

Jones, A. E. and Wolff, E. W.: An analysis of the oxidation potential of the South Pole boundary layer and the influence of stratospheric ozone depletion, J. Geophys. Res., 108(D18), 4565, doi:10.1029/2003JD003379, 2003.

Jones, A. E., Weller, R., Wolff, E. W., and Jacobi, H.-W.: Speciation and rate of photochemical $\mathrm{NO}$ and $\mathrm{NO}_{2}$ production in Antarctic snow, Geophys. Res. Lett., (27), 345-348, 2000.

Jones, A. E., Anderson, P. S., Wolff, E. W., Turner, J., Rankin, A. M., and Colwell, S. R.: A role for newly-forming sea ice in springtime polar tropospheric ozone loss? Observational evidence from Halley station, Antarctica, J. Geophys. Res., 111, D08306, doi:10.1029/2005JD006566, 2006.

Kadokura, A., Yamagishi, H., Sato, N., Nakano, K., and Rose, M. C.: Unmanned magnetometer network observation in the 44th Japanese Antarctic Research Expedition: Initial results and an event study on auroral substorm evolution, Polar Sci., 2, 223 235, doi:10.1016/j.polar.2008.04.002, 2008.

Knepp, T. N., Bottenheim, J., Carlsen, M., Carlson, D., Donohoue, D., Friederich, G., Matrai, P. A., Netcheva, S., Perovich, D. K., Santini, R., Shepson, P. B., Simpson, W., Valentic, T., Williams, C., and Wyss, P. J.: Development of an autonomous sea ice tethered buoy for the study of ocean-atmosphere-sea ice-snow pack interactions: the O-buoy, Atmos. Meas. Tech., 3, 249-261, doi:10.5194/amt-3-249-2010, 2010.

Legrand, M., Preunkert, S., Jourdain, B., Gallée, H., Goutail, F., Weller, R., and Savarino, J.: Year round record of surface ozone at coastal (Dumont d'Urville) and inland (Concordia) sites in East Antarctica, J. Geophys. Res., 114, D20306, doi:10.1029/2008JD011667, 2009.

Simpson, W. R., von Glasow, R., Riedel, K., Anderson, P., Ariya, P., Bottenheim, J., Burrows, J., Carpenter, L. J., Frieß, U., Goodsite, M. E., Heard, D., Hutterli, M., Jacobi, H.-W., Kaleschke, L., Neff, B., Plane, J., Platt, U., Richter, A., Roscoe, H., Sander, R., Shepson, P., Sodeau, J., Steffen, A., Wagner, T., and Wolff, E.: Halogens and their role in polar boundary-layer ozone depletion, Atmos. Chem. Phys., 7, 4375-4418, doi:10.5194/acp-74375-2007, 2007.

Slusher, D. L., Neff, W. D., Kim, S., Huey, L. G., Wang, Y., Zeng, T., Tanner, D. J., Blake, D. R., Beyersdorf, A., Lefer, B. L., Crawford, J. H., Eisele, F. L., Mauldin, R. L., Kosciuch, E., Buhr, M. P., Wallace, H. W., and Davis, D. D.: Atmospheric chemistry results from the ANTCI 2005 Antarctic plateau airborne study, J. Geophys. Res., 115(D7), D07304, doi:10.1029/2009JD012605, 2010.

Wessel, S., Aoki, S., Winkler, P., Weller, R., Herber, A., Gernandt, H., and Schrems, O.: Tropospheric ozone depletion in polar regions: A comparison of observations in the Arctic and Antarctic, Tellus B, 50, 34-50, 1998.

Wilson, K. L. and Birks, J. W.: Mechanism and elimination of a water vapor interference in the measurements of ozone by UV absorbance, Environ. Sci. Technol., 40, 6361-6367, doi:10.1021/es052590c, 2006. 